
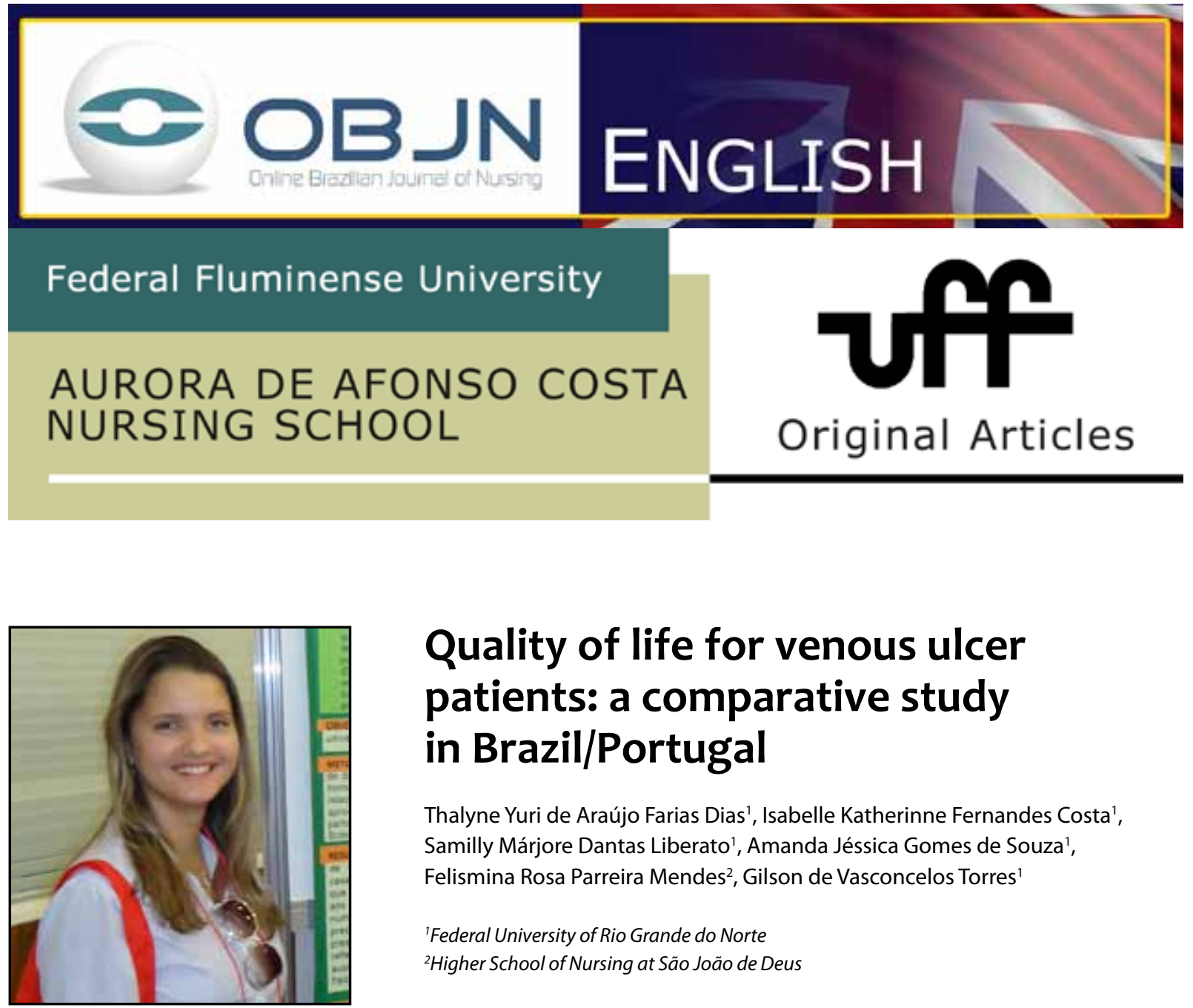

\title{
Quality of life for venous ulcer patients: a comparative study in Brazil/Portugal
}

\author{
Thalyne Yuri de Araújo Farias Dias', Isabelle Katherinne Fernandes Costa', \\ Samilly Márjore Dantas Liberato' ${ }^{1}$, Amanda Jéssica Gomes de Souza', \\ Felismina Rosa Parreira Mendes², Gilson de Vasconcelos Torres ${ }^{1}$ \\ ${ }^{1}$ Federal University of Rio Grande do Norte \\ ${ }^{2}$ Higher School of Nursing at São João de Deus
}

\section{ABSTRACT}

Introduction:Venous ulcers are a public health problem that affect quality of life (QOL) and are determined by socioeconomic context, health assistance and lesion characteristics.

Aim: To compare the QOL of patients suffering from venous ulcers in Natal/Brazil with patients in Evora/ Portugal.

Method: Comparative and quantitative research involving 170 individuals suffering from venous ulcers, using the SF-36 instrument.

Results: In Portugal, all dominion and dimension averages were higher than in Brazil, especially regarding social aspects (70.62). There were also a larger number of people with positive treatment characteristics. As for the lesion characteristics, these affected QOL dominions and dimensions in both countries.

Discussion: The socioeconomic reality in Portugal is different from that in Brazil; the former has a larger variety and quantity of material resources available for lesion treatment.

Conclusion: $\mathrm{QOL}$ in Portugal is better than in Brazil in terms of the aspects under consideration in this research.

Descriptors: Nursing; Quality of Life; Varicose Ulcer 


\section{INTRODUCTION}

The concept of quality of life $(\mathrm{QOL})$ is linked to behavior, living conditions and lifestyles; it includes the notions of sustainability and human ecology and relates to democracy, development, and human and social rights. In terms of health, these concepts are correlated to a social product collectively constructed for comfort and tolerance standards that a society sets as parameters for itself ${ }^{(1)}$.

In this context, one notices that the QOL regarding health involves concepts that go beyond the control of symptoms, mortality reduction and increase in life expectancy. As it is a well-known and widely used term, $\mathrm{QOL}$ has been used in numerous contexts and has attracted the attention of professionals from a variety of fields, especially in the health sciences ${ }^{(2)}$. The appreciation of the concept indicates that $\mathrm{QOL}$ reflects an increased concern for a patient's holistic wellbeing. The main aim of the treatment is no longer simply curing patients, but also reintegrating them into society by providing them with the optimum conditions allowing them to lead normal lives. In other words, to live healthily and adequately ${ }^{(3-4)}$.

In this context, as an individual faces chronic venous disease, a disorder in the functioning of the vein system caused by valvular weakness, he/she may no longer be able to perform vital daily activities such as work. As this disease affects all age groups and directly affects socioeconomic levels, it can lead to early retirement, even though the individual is at his/her most productive stage of life ${ }^{(3,5)}$.

This mainly happens because Chronic Vein Disease is one of the causes of venous ulcers, a chronic lesion in the legs, which is, like all chronic diseases, something patients must deal with on a regular basis for years ${ }^{(5)}$.

In Brazil, venous ulcers are a serious health problem for public healthcare, due to the large number of patients with changes in skin integrity, even though the records of its treatment are hard to come by. The increasing number of patients with ulcers has increased public spending in the Public Health System (SUS in Portuguese), and directly affected the QOL of the population ${ }^{(5)}$.

As for Portugal, in a study done in Lisbon on a population of 186,000 residents registered in health centers or hospitals, 263 persons were diagnosed as having leg ulcers (ulcers that were found to be active), which represents a global prevalence of $1.4 / 1000$ persons. The prevalence in men was $1.3 / 1000$ and in women $1.5 / 1000^{(6)}$.

Healing ulcers is the desired treatment outcome, but other outcomes are of interest, such as changes in health habits and QOL. As the human body is an integrated system, and a particular problem affects it as a whole, the patient's social and economic life is directly affected. Therefore, by caring for an individual's well-being holistically, the outcome is the eventual healing of the ulcer ${ }^{(7)}$.

In healthcare, the multidisciplinary approach has changed in recent years. Subjective variables have been used to measure the $\mathrm{QOL}$ that reflects the perceptions patients have of their own well-being. Researchers are not the only ones interested in this aspect - healthcare practitioners have also shown interest in this aspect $^{(2)}$.

Interest in researching this topic arose after one of the authors had the opportunity to undertake a post-doctoral internship in Portugal. In light of this experience, it became apparent there was a need for a comparative study on the QOL of individuals suffering from ulcers in different socioeconomic realities, as one scenario was in a first-world country (Portugal) and the other in a developing country (Brazil).

From this standpoint, this study aims to compare the QOL (measured using the Short 
Form 36 or SF-36) between patients with VU treated at a renowned university hospital in Brazil, and those receiving treatment at Primary Healthcare Units (CSP) in Portugal.

\section{METHOD}

This is an analytical, comparative, and cross-sectional study with a quantitative approach for treatment and data analysis, with the aim of comparing the QOL of venous ulcer patients treated at a renowned hospital in Natal/RN, Brazil with those being treated in healthcare units in Évora/Portugal.

Participant selection was based on the following criteria for inclusion: a history of venous ulcers and aged over 18 years. The criterion for exclusion was a request to cancel participation. The study sample was by accessibility for a period of six months (June to November 2011) resulting in 100 individuals with VU in Natal/ Brazil and 70 in Évora/Portugal.

Flowchart 1: Study development flowchart. Natal-RN/Brazil 2012.

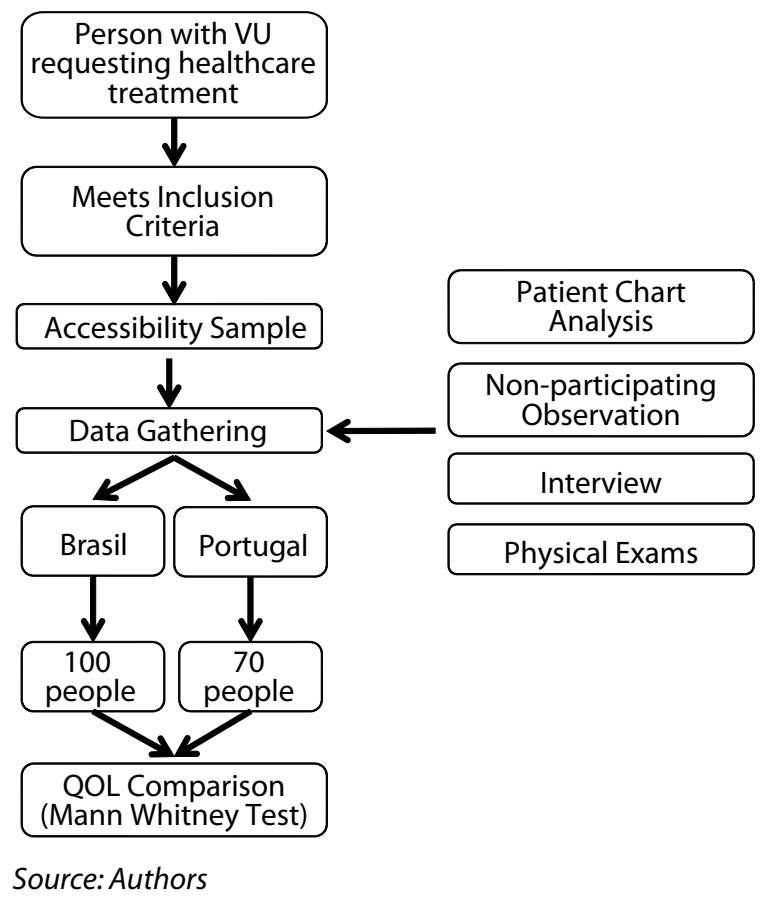

Two instruments were used in this study for data gathering. The first was a structured interview form dealing with socio-demographic characteristics, while the second was an instrument for QOL in terms of health, the SF-36.

SF-36 is a multidimensional questionnaire consisting of 36 items grouped in 8 components ${ }^{(8)}$ : functional capacity (10 items), physical aspects (4 items), pain ( 2 items), general health condition (5 items), energy (4 items), social aspects ( 2 items), emotional aspects ( 3 items) and mental health ( 5 items). Additionally, there was a comparative evaluation question regarding the patient's current state of health and that of a year before. This was of utmost importance for disease diagnosis. This instrument evaluated the negative aspects (disease) as much as the positive aspects (well-being). The calculation of each dominion and dimension of the SF-36 are described in the user manual ${ }^{(8)}$.

Furthermore, this research studied the variables for socio-demographic characterization, health (gender, age group, marital status, academic background, income, occupation), treatment characteristics (adequacy of bandage material, wound dressing outside of hospitals, use of compressive therapy, VU treatment duration, location of VU treatment, orientation, lab tests and specific tests, number of consultations with an angiologist, references and counter references, records of clinical findings), and VU characteristics (relapses, duration of current wound, wound location, hospital bed conditions, amount of exudates, odor, tissue loss, pain, infection symptoms and swabs).

The healthcare variations and clinical aspects of the wound were classified into nominal and dichotomous categories, which resulted in a score determined by a positive (value- $=1$ ) or negative factor (value $=0$ ), representing the quantitative variables. Following this, these variables were re-classified into nominal variables, using the median as a parameter. 
The study complied with all the ethical principles outlined in the Helsinki Declaration of the World Medical Association, and was assessed by Research Ethics Committee at UFRN ${ }^{(9)}\left(n^{\circ} 279 / 09\right)$ and by the Ethics Committee of the Department of Health and Well-being at the University of Évora in Portugal, protocol no 10028/10.

A team of researchers and two academic scholars with bachelor and post-graduate degrees in nursing gathered the data after the participants had signed an Informed Consent form. The team collected research data using patient chart data, patient observations, interviews and physical examinations.

The data was transferred to a database using a Microsoft Excel 2007 spreadsheet and, after the necessary corrections, transferred to a statistics program for analysis.

In the statistics program, the descriptive analysis used absolute and relative frequencies, averages, minimum and maximum standard deviation, inferential analysis for variable crosschecking, with a level of statistical significance at a $p$-value $<0.05$. The Mann Whitney Test was applied and used to verify significant differences between the score averages for socio-demographic condition variables, health conditions, healthcare, clinical aspects of the lesion, and the dominions and dimensions for QOL.

\section{RESULTS}

In the socio-demographic characterization of this study, the majority consisted of persons aged over 60 in both Brazil (50\%) and Portugal (82\%); female (69\% in Brazil and 62.9\% in Portugal); in married/stable relationships (62\% in Brazil and $57.1 \%$ in Portugal); low level of education (83\% in Brazil and 90\% in Portugal), with a statistical significance of $p=0.004$.
In Brazil, the majority was made up of persons with a profession/occupation (56.0\%) and personal income lower than the minimum salary (70\%). In Portugal, $84.3 \%$ had no profession/occupation, being statistically significant $(p=0.001)$, but had a personal income higher than the minimum wage (98.6\%), which was also statistically significant $(p=0.001)$.

Table 1 shows the maximum and minimum values, standard deviations, and averages obtained in each dominion and dimension of the SF-36 instrument in Brazil and Portugal.

The averages of the dominions evaluated in the SF-36 for Brazil were low, especially in terms of physical aspects. In Portugal, the averages related to all dominions were higher, especially in terms of social aspects, with an average of 70.0.

As for the physical health dominion, which includes the averages for the functional and physical dominions, pain, overall health condition and stamina, the study offers a broad view of the relationship between the research subjects and the activities that are affected by physical aspects, which the lesion may or may not interfere with. The mental health dimension was calculated using the averages of overall health condition, stamina, social function, emotional aspects and mental health. By using this variable, the patients' psychological conditions, mood and interaction with everyday life could be observed. The minimum values of these dimensions were the same in both countries. However, the maximum values were clearly higher in Portugal.

As for the treatment characteristics in Brazil, 69 patients had up to 3 positive characteristics and 31 patients were found to have from 4 to 10. These were then cross-checked with the dominions. After the averages were compared, functional capacity $(p=0.005)$, pain $(p=0.001)$ and physical health dimension $(p=0.001)$ all showed levels of statistical significance. In Por- 
Table 1 - Maximum/minimum values, standard deviation and average of dimensions and dominions of SF-36. Natal-RN/Brazil, 2012

\begin{tabular}{lcccccccc}
\hline \multirow{2}{*}{\begin{tabular}{c} 
Dominions and dimen- \\
\multicolumn{1}{c}{ sions of SF-36 }
\end{tabular}} & \multicolumn{2}{c}{ Average } & \multicolumn{2}{c}{ Standard Deviation } & \multicolumn{2}{c}{ Minimum } & \multicolumn{2}{c}{ Maximum } \\
\cline { 2 - 8 } & Brazil & Portugal & Brazil & Portugal & Brazil & Portugal & Brazil & Portugal \\
\hline Functional Capacity & 14.85 & 41.00 & 20.21 & 33.3 & 0 & 0 & 100 & 100 \\
Physical Aspects & 4.75 & 40.71 & 16.16 & 12.5 & 0 & 0 & 100 & 100 \\
Pain & 33.97 & 56.61 & 27.44 & 57.0 & 0 & 0 & 100 & 100 \\
Overall Health condition & 36.01 & 44.50 & 15.69 & 47.0 & 5 & 0 & 77 & 87 \\
Stamina & 42.25 & 61.43 & 23.91 & 65.0 & 5 & 0 & 100 & 100 \\
Social Aspects & 27.38 & 70.62 & 24.29 & 88.0 & 0 & 0 & 100 & 100 \\
Emotional Aspects & 32.00 & 57.09 & 45.92 & 67.0 & 0 & 0 & 100 & 100 \\
Mental Health & 55.84 & 66.57 & 24.58 & 76.0 & 8 & 8 & 100 & 100 \\
Physical Health Dimension & 26.24 & 48.79 & 13.71 & 50.5 & 4 & 4 & 56 & 93 \\
Mental Health Dimension & 38.68 & 60.07 & 19.52 & 65.0 & 5 & 5 & 85 & 97 \\
\hline
\end{tabular}

Source: Authors

Table 2 - Characteristics of positive assistance based on dominions and dimensions of the SF-36. Natal-RN/Brazil, 2012.

\begin{tabular}{|c|c|c|c|c|c|c|c|}
\hline \multirow{2}{*}{$\begin{array}{c}\text { SF-36 dimensions and } \\
\text { dominions }\end{array}$} & \multirow{2}{*}{$\begin{array}{l}\text { Positive assistance } \\
\text { characteristics }\end{array}$} & \multicolumn{2}{|r|}{$\mathrm{n}$} & \multicolumn{2}{|c|}{ Average } & \multicolumn{2}{|c|}{$\begin{array}{c}\text { p-value } \\
\text { (Mann-Whitney) }\end{array}$} \\
\hline & & Brazil & Portugal & Brazil & Portugal & Brasil & Portugal \\
\hline \multirow{2}{*}{ Functional Capacity } & Up to 3 & 69 & 8 & 45.25 & 23.94 & \multirow{2}{*}{0.005} & \multirow{2}{*}{0.087} \\
\hline & from 4 to 10 & 31 & 62 & 62.19 & 36.99 & & \\
\hline \multirow{2}{*}{ Physical Aspects } & Up to 3 & 69 & 8 & 48.62 & 28.38 & \multirow{2}{*}{0.074} & \multirow{2}{*}{0.252} \\
\hline & from 4 to 10 & 31 & 62 & 54.69 & 36.42 & & \\
\hline \multirow{2}{*}{ Pain } & Up to 3 & 69 & 8 & 42.92 & 35.5 & \multirow{2}{*}{0.001} & \multirow{2}{*}{1} \\
\hline & from 4 to 10 & 31 & 62 & 67.37 & 35.5 & & \\
\hline \multirow{2}{*}{ Overall health } & Up to 3 & 69 & 8 & 47.26 & 44.5 & \multirow{2}{*}{0.095} & \multirow{2}{*}{0.183} \\
\hline & from 4 to 10 & 31 & 62 & 57.71 & 34.34 & & \\
\hline \multirow{2}{*}{ Stamina } & Up to 3 & 69 & 8 & 47.16 & 33.31 & \multirow{2}{*}{0.085} & \multirow{2}{*}{0.746} \\
\hline & from 4 to 10 & 31 & 62 & 57.94 & 35,78 & & \\
\hline \multirow{2}{*}{ Social Aspects } & Up to 3 & 69 & 8 & 47.25 & 35.56 & \multirow{2}{*}{0.083} & \multirow{2}{*}{0.992} \\
\hline & from 4 to 10 & 31 & 62 & 57.73 & 35.49 & & \\
\hline \multirow{2}{*}{ Emotional Aspects } & Up to 3 & 69 & 8 & 49.85 & 37.56 & \multirow{2}{*}{0.685} & \multirow{2}{*}{0.747} \\
\hline & from 4 to 10 & 31 & 62 & 51.95 & 35.23 & & \\
\hline \multirow{2}{*}{ Mental Health } & Up to 3 & 69 & 8 & 47.02 & 38.88 & \multirow{2}{*}{0.073} & \multirow{2}{*}{0.617} \\
\hline & form 4 to 10 & 31 & 62 & 58.24 & 35.06 & & \\
\hline \multirow{2}{*}{ Physical Health Dimension } & Up to 3 & 69 & 8 & 43.39 & 29.31 & \multirow{2}{*}{0.001} & \multirow{2}{*}{0.361} \\
\hline & from 4 to 10 & 31 & 62 & 66.32 & 36.3 & & \\
\hline \multirow{2}{*}{ Mental health dimension } & Up to 3 & 69 & 8 & 47.22 & 35.5 & \multirow{2}{*}{0.091} & 1 \\
\hline & from 4 to 10 & 31 & 62 & 57.81 & 35.5 & & \\
\hline
\end{tabular}

Source: authors

tugal, the number of people that had 4 to 10 positive characteristics was higher -62 patients whose averages were balanced with the other 8 participants with up to 3 positive characteristics. This data shows just how important the quality of provided treatment is in terms of the QOL for venous ulcer patients.
In terms of the lesion characteristics in Brazil, there was a balance in the distribution, in that 50 patients showed up to 4 positive characteristics, and 50 showed 5 to 10 positive characteristics. When these were analyzed with the dominions and dimensions, 7 were found to be statistically significant: functional capacity 
Table 3 - Averages for positive characteristics of venous ulcers based on SF-36 dominions Natal-RN/ Brazil, 2012.

\begin{tabular}{|c|c|c|c|c|c|c|c|}
\hline \multirow{2}{*}{$\begin{array}{c}\text { SF-36 dominions and } \\
\text { dimensions }\end{array}$} & \multirow{2}{*}{$\begin{array}{l}\text { Positive lesion } \\
\text { characteristics }\end{array}$} & \multicolumn{2}{|r|}{$\mathbf{n}$} & \multicolumn{2}{|c|}{ Average } & \multicolumn{2}{|c|}{$\begin{array}{c}\text { p-value } \\
\text { (Mann-Whitney) }\end{array}$} \\
\hline & & Brazil & Portugal & Brazil & Portugal & Brazil & Portugal \\
\hline \multirow{2}{*}{ Functional Capacity } & Up to 4 & 50 & 24 & 39.54 & 25.15 & \multirow{2}{*}{0.001} & \multirow{2}{*}{0.002} \\
\hline & from 5 to 10 & 50 & 46 & 61.46 & 40.9 & & \\
\hline \multirow{2}{*}{ Physical Aspects } & Up to 4 & 50 & 24 & 49.09 & 29.46 & \multirow{2}{*}{0.371} & \multirow{2}{*}{0.05} \\
\hline & from 5 to 10 & 50 & 46 & 51.91 & 38.65 & & \\
\hline \multirow{2}{*}{ Pain } & Up to 4 & 50 & 24 & 37.34 & 29.44 & \multirow{2}{*}{0.001} & \multirow{2}{*}{0.07} \\
\hline & from 5 to 10 & 50 & 46 & 63.66 & 38.66 & & \\
\hline \multirow{2}{*}{ Overall health } & Up to 4 & 50 & 24 & 43.35 & 35.98 & \multirow{2}{*}{0.014} & \multirow{2}{*}{0.887} \\
\hline & from 5 to 10 & 50 & 46 & 57.65 & 35.25 & & \\
\hline \multirow{2}{*}{ Stamina } & Up to 4 & 50 & 24 & 40.91 & 31.65 & \multirow{2}{*}{0.001} & \multirow{2}{*}{0.251} \\
\hline & from 5 to 10 & 50 & 46 & 60.09 & 37.51 & & \\
\hline \multirow{2}{*}{ Social Aspects } & Up to 4 & 50 & 24 & 44.12 & 30.58 & \multirow{2}{*}{0.022} & \multirow{2}{*}{0.12} \\
\hline & from 5 to 10 & 50 & 46 & 56.88 & 38.07 & & \\
\hline \multirow{2}{*}{ Emotional Aspects } & Up to 4 & 50 & 24 & 46.7 & 28.75 & \multirow{2}{*}{0.114} & \multirow{2}{*}{0.034} \\
\hline & from 5 to 10 & 50 & 46 & 54.3 & 39.02 & & \\
\hline \multirow{2}{*}{ Mental Health } & Up to 4 & 50 & 24 & 46.17 & 29.63 & \multirow{2}{*}{0.135} & \multirow{2}{*}{0.08} \\
\hline & from 5 to 10 & 50 & 46 & 54.83 & 38.57 & & \\
\hline \multirow{2}{*}{ Physical Health Dimension } & Up to 4 & 50 & 24 & 36.64 & 28.04 & \multirow{2}{*}{0.001} & \multirow{2}{*}{0.027} \\
\hline & from 5 to 10 & 50 & 46 & 64.36 & 39.39 & & \\
\hline \multirow{2}{*}{ Mental health dimension } & Up to 4 & 50 & 24 & 41.87 & 29.92 & \multirow{2}{*}{0.003} & דתחת \\
\hline & from 5 to 10 & 50 & 46 & 59.13 & 38.41 & & 0.091 \\
\hline
\end{tabular}

Source: Authors

$(p=0.001)$, pain $(p=0.001)$, overall health condition $(p=0.014)$, stamina $(p=0.001)$, social aspects $(p=0.022)$, physical health dimension $(p=0.001)$ and mental health dimension $(p=0.003)$.

In Portugal, only 24 patients had up to 4 positive characteristics, as the majority (46 patients), had 5 to 10 positive characteristics. Based on the cross-checking between this data and the dimensions and dominions, functional capacity $(p=0.002)$, physical aspects $(p=0.050)$, emotional aspects $(\rho=0,034)$, and physical health dimension ( $p=0.027$ ) were all found to be statistically significant. This shows how, the more positive characteristics a lesion has, the greater the contribution to QOL improvement.

\section{DISCUSSION}

This study found that in both countries most of the participants were female and aged

over 60 . The findings are corroborated by other research that demonstrate how most venous ulcer cases occur in women aged over $60^{(10,11)}$.

Low levels of education were prevalent with $90 \%$ in Portugal, even though it is a first-world country. Some research demonstrates that most patients have low levels of education which hinders their access to information, assimilation of relevant healthcare habits (especially those regarding lesions), changes in behavior and household habits, or understanding the education for prevention they receive ${ }^{(12,13)}$.

As for the participants' occupations, it was found that in Portugal most of the participants $(84.3 \%)$ were not employed $(p=0.001)$, while in Brazil, 56\% said they were employed. This implies more time spent sitting or standing, thus exacerbating any lesions and affecting the QOL. Most of the participants said that they work as house cleaners, farmers, cooks, housekeepers, tailors, drivers, salespersons or civil servants. 
Similar occupations were found in other studies, which show the prevalence of occupations with reduced mobility, long periods of standing and with only short breaks, which may all be risk factors for the onset of venous hypertension in the lower limbs and chronic venous ulcers ${ }^{(11,14)}$.

Income levels below the minimum salary was predominant in Brazil (76.0\%), as opposed to Portugal, in which $98.6 \%$ of the participants with venous ulcers have an income higher than the minimum salary, statistically significant at $\mathrm{p}=0.001$.

Household income is an important factor in planning, as it dictates living conditions of this population, and frequently limits the efficacy of preventive measures by prolonging the treatment and chronicity of the lesions ${ }^{(11,14)}$. From another perspective, venous ulcers entail additional expenses, which may be a destabilizing factor in terms of household finance.

In this study, the dominion and dimensional averages of SF-36 were higher in Portugal, as were the maximum values for physical and mental health dimensions, pointing to the better overall QOL in that country compared with Brazil in terms of the aspects under consideration.

For patients suffering from chronic disease, especially those with venous ulcers, a low QOL makes carrying out simple everyday activities considerably more difficult ${ }^{(15)}$. Some of the most serious consequences of venous ulcers for patients are work absenteeism, decreased productivity, early retirement, unemployment and even social isolation ${ }^{(3,16)}$.

One particular study done with VU patients showed that, in terms of employment status, $62.5 \%(n=25)$ of the participants were retired (with an income), 25\% ( $n=10)$ were actively employed, and $12.5 \%(n=5)$ were unemployed with no means of income ${ }^{(17)}$.

In Brazil, this study found that most of the participants had few positive treatment charac- teristics (up to 3), and a minority had a larger amount of positive treatment characteristics. From this point of view, one can assume that the treatment offered in Brazil has few positive characteristics, and this may have influenced the low scores in the SF-36 dominions and dimensions. In Portugal, the available treatment had more characteristics that are positive for most of the participants, even though the difference between the averages was not statistically significant.

This comparative study between Brazil and Portugal found that the latter had a larger variety and quantity of material resources available for treating clients' lesions ${ }^{(18)}$.

In both countries, lesion characteristics affected the dominions and dimensions for QOL. The results referring to functional capacity show that people with venous ulcers face significant obstacles when performing everyday activities, and these limitations are linked to low QOL. It is clear in this study that this dominion received positive, direct and significant influence from Provided Treatment $(p=0.001)$ in Brazil and lesion characteristics $(p=0.001)$ in Brazil and $p=0.002$ in Portugal.

These results regarding functional capacity are similar to the findings of another piece of research done in Portugal. It showed how simple and routine activities such as going up or down stairs, moving about the house, or simply standing without support for a short period of time, become difficult tasks on a daily basis for a person affected by venous ulcers. Likewise, activities like showering or getting dressed, walking short distances and getting out of bed turn out to be complicated ${ }^{(15)}$.

The data mentioned above is corroborated by findings from a descriptive study done in Brazil which aimed to understand what lesions mean for people with chronic ulcers. The study participants reported a range of physical limitations, varying in intensity, which go from reliance 
on external help for simple daily tasks, to inability to move around ${ }^{(19)}$.

Consequently, this inability to move about freely has multiple implications, "forcing" patients to reorganize their daily activities and, in some cases, causing them to feel dependent on others to move about, and to be able to socialize with others ${ }^{(15)}$.

In Brazil, the overall health condition was statistically significant when linked to treatment characteristics $(p=.001)$ and lesion characteristics $(p=0.001)$. The stamina dominion was also statistically significant when linked to lesion characteristics $(p=0.001)$.

The physical health dimension stood out in Brazil and Portugal when cross-examined with the lesion characteristics. Some studies demonstrate how sleeping disorders are a reality for people with venous ulcers, which are usually linked to pain. Fatigue and tiredness, resulting from these disorders, are conditions that are constantly present in the lives of patients who live with a chronic wound, and may have obvious consequences in terms of stamina, energy, and the patients' ability to carry out their personal and professional activities ${ }^{(15)}$.

\section{CONCLUSION}

The averages for the dominions analyzed using SF-36 were low in Brazil, especially in terms of physical aspects and functional capability. On the other hand, in Portugal, all the averages for dominions and dimensions were higher, especially social aspects. Likewise, there were also more people with a higher number of positive treatment characteristics. As for lesion characteristics, they affected all dominions and dimensions of QOL; in Brazil, the dominions for functional capability, pain, overall health conditions, stamina, and social aspects were all statistically significantly higher, as were the physical health and mental health dimensions. In comparison, in Portugal, functional capability, physical aspects, emotional aspects, and the physical health dimension were statistically significant.

These findings show how the quality of treatment and lesion aspects is important to the QOL of a person suffering from venous ulcers. Thus, nurses and any professionals providing direct treatment must be capable of monitoring the impact of their interventions through continual evaluation, since there are dynamic changes in the signs and symptoms each patient demonstrates.

Thus, it is clear that, in order to improve the QOL of patients with venous ulcers, there must be holistic and adequate treatment, with multi-professional and continuous assistance planning, in addition to the use of instruments that provide global evaluations, based on real contexts, to truly improve the QOL of these patients.

\section{REFERENCES}

1. Budó MLD, Mattioni FC, Machado TS, Ressel LB, Lopes LFD. Quality of life and health promotion through the perspective of the users of the family health strategy. Online Braz J Nurs [Internet]. 2008; [cited 2012 Aug 08]; 7(1). Available from: http://www.objnursing.uff.br/index.php/nursing/article/view/1104

2. Faria E, Blanes L, Hochman B, Mesquita Filho M, Ferreira L. Health-related Quality of Life, Selfesteem, and Functional Status of Patients With Leg UIcer. Wounds [Internet]. 2011 [cited 2012 Aug 20]; 23(1):4-10. Available from: http://www.woundsresearch.com/files/wounds/Faria_WOUNDS.pdf

3. Santos RFFN, Porfírio GJM, Pitta GBB. A diferença na qualidade de vida de pacientes com doença venosa crônica leve e grave. J Vasc Bras [Internet]. 2009 [cited 2011 Feb 15]; 8(2): 143-7. Availa- 
ble from: http://www.scielo.br/pdf/jvb/v8n2/ a08v8n2.pdf

4. Yamada BFA, Santos VLCG. Construção e validação do Índice de Qualidade de Vida de Ferrans \& Powers: versão feridas. Rev Esc Enferm USP [Internet]. 2009 [cited 2011 Feb 17]; 43(nesp):1105-13. Available from: http://www.scielo.br/scielo.php?script $=$ sci_arttext $\&$ pid $=$ S0080$-62342009000500015 \&$ Ing=pt. http://dx.doi. org/10.1590/S0080-62342009000500015

5. Silva FAA, Freitas CHA, Jorge MSB, Moreira TMM, Alcântara MCM. Enfermagem em estomaterapia: cuidados clínicos ao portador de úlcera venosa. Rev bras enferm [Internet]. 2009 [cited 2012 Sep 10]; 62(6): 889-3. Available from: http://www.scielo.br/scielo.php?script=sci_arttext\&pid=S0034$-71672009000600014 \&$ Ing=pt. http://dx.doi. org/10.1590/S0034-71672009000600014

6. Pina E, Furtado K, Franks PJ, Moffatt CJ. Leg Ulceration in Portugal: Prevalence and Clinical History. Eur J Vasc Endovasc Surg [Internet]. 2005 [cited 2012 Set 10];29(5):549-53. Available from: http:// www.ff.ul.pt/FCT/PTDC/SAU-BEB/098801/2008/ Pina\%20et\%20al_EJVES_2005.pdf

7. Jull A, Parag V, Walker N, Rodgers A. Responsiveness of generic and disease-specific health-related quality of life instruments to venous ulcer healing. Wound Repair Regen [Internet]. 2010 [cited 2012 Sep 10]; 18(1): 26-30. Available from: http://www.ncbi.nlm.nih.gov/pub$\mathrm{med} / 20082678$

8. Ware JE, Kosinki M, Keller SD. SF-36 physical and mentalhealth summary scores: a user's manual. Boston: The Health Institute; 1994

9. Ministério da Saúde (Brasil). Conselho Nacional de Saúde. Resolução no 196/96 de 10 outubro de 1996. Estipula diretrizes e normas regulamentadoras da pesquisa envolvendo seres humanos. Diário Oficial da União 16 out 1996.

10. Santos FAAS, Melo RP, Lopes MVO. Caracterization of health status with regard tissue integrity and tissue perfusion in patients with venous ulcers according to the nursing outcomes classification. J Vasc Nurs [Internet]. 2010[cited 2012 June 17];18(1):14-20. Available from: http:// www.sciencedirect.com/science/article/pii/ S1062030309001277
11. Macedo EAB, Oliveira AKA, Melo GSM, Nobrega WG, Costa IKF, Dantas DV, et al. Caracterização sócio-demográfica dos pacientes com úlcera venosa atendidos em um hospital universitário. Rev enferm UFPE [Internet]. 2010 [cited $2012 \mathrm{Feb}$ 17]; 4(n०esp):1863-7. Available from: http://www. ufpe.br/revistaenfermagem/index.php/revista/ article/view/1475/pdf_125

12. Azoubel R, Torres GV, Silva LWS, Gomes FV, Reis LA. Efeitos da terapia física descongestiva na cicatrização de úlceras venosas. Rev Esc Enferm USP [Internet]. 2010 [cited 2012 Feb 17]; 44(4):1085-92. Available from: http://www.scielo.br/scielo.php?script $=$ sci_arttext \&pid $=$ S0080 $-62342010000400033 \&$ Ing=pt. http://dx.doi. org/doi:10.1590/S0080-62342010000400033

13. Melo EM, Teles MS, Teles RS, Barbosa IV, Studart RMB, Oliveira MM. Avaliação dos fatores interferentes na adesão ao tratamento do cliente portador de pé diabético. Rev educ form enferm [Internet]. 2011 [cited 2012 June 17]; 3(5):37-44. Available from: http://www.index-f.com/referencia/2011/r35-037.php

14. Nobrega WG, Melo GSM, Costa IKF, Dantas DV, Macedo EAB, Torres GV. Changes in patients' quality of life with venous ulcers treated at the outpatient clinic of a university hospital. Rev enferm UFPE [serial on the Internet]. 2011 [cited 2012 feb 17]; 5(2):1005-6. Available from: http://www.revista.ufpe.br/revistaenfermagem/index.php/revista/article/viewFile/1478/ pdf_428

15. Sousa FAMR. O corpo que não cura: vivências de pessoas com úlceras venosas de perna [dissertação]. Coimbra: Universidade do Porto; 2009.

16. Salomé GM. Processo de viver do portador com ferida crônica: atividades recreativas, sexuais, vida social e familiar. Saúde Coletiva [Internet]. 2010 [cited 2012 feb 17]; 07(46):300-4. Available from: http://redalyc.uaemex.mx/redalyc/ pdf/842/84215678004.pdf

17. Jorge $S A$, Guimarães $C P$, Henriquez DAD, Dantas SRPE. Avaliação do Nível de Ansiedade de Pacientes com Úlceras Venosas. Revista Estima [Internet]. 2009 [cited 2012 Feb 17];7(4): 12-9. Available from: http://www.revistaestima.com. 
br/index.php?option=com_content\&view=arti cle\&id=108:artigo-original\&catid=13:edicao-vol$-74 \&$ Itemid $=84$

18. Silva DS, Hahn GV. Treating venous ulcers: reality in Brazil and Portugal. Rev Enferm UFSM[Internet]. 2012 [cited 2012 Feb 17]; 2(2):330-8. Available from: http://cascavel.ufsm.br/revistas/ojs-2.2.2/ index.php/reufsm/article/view/4967/3757

19. Lara MO, Pereira Júnior AC, Pinto JSF, Vieira NF, Wichr P. Significado da ferida para portadores de úlceras crônicas. Cogitare Enferm [Internet]. 2011 [cited 2012 Dec 17]; 16(3):471-7. Available from: http://ojs.c3sl.ufpr.br/ojs2/index.php/cogitare/ article/view/20178/16232
Authors

Thalyne Yuri de Araújo Farias Dias - Author and Project researcher

Isabelle Katherinne Fernandes Costa - Author and Project researcher

Samilly Márjore Dantas Liberato - Author and Project researcher

Amanda Jéssica Gomes de Souza - Author and Project researcher

Felismina Rosa Parreira Mendes - Research Project Advisor and Final Reviewer in Portugal

Gilson de Vasconcelos Torres - Research Project Advisor and Final Reviewer in Brazil

Received: 02/04/2013

Revised: 15/05/2013

Approved: 04/06/2013 